\title{
From bisphenol A to bisphenol $F$ and a ban of mustard due to chronic low-dose exposures?
}

\author{
Daniel R. Dietrich ${ }^{1} \cdot$ Jan G. Hengstler $^{2}$
}

Received: 11 January 2016 / Accepted: 14 January 2016 / Published online: 2 February 2016

(C) Springer-Verlag Berlin Heidelberg 2016

Recently, Otmar Zoller and colleagues from the Swiss Federal Food Safety and Veterinary Office in Bern, Switzerland, published a study of high interest for the sometimes heated debate on bisphenol A (BP-A) and its ban in some consumer products: mustard contains the BP-A analog bisphenol $\mathrm{F}$ (BP-F) at surprisingly high concentrations (Zoller et al. 2016). In 61 samples of mustard produced in Europe, the mean BP-F concentration was found to be $1.85 \mathrm{mg} / \mathrm{kg}$ and the highest value was $8.35 \mathrm{mg} / \mathrm{kg}$ (Zoller et al. 2016). BP-F was detected primarily in white mustard (Sinapis alba) samples, the basis of sweet or mild mustard, as used, for example, in the typical ball-park hot dog with French's mustard (http://www.frenchs.com/products/mustard/). Indeed, the 19 mild mustard samples analyzed by Zoller et al. (2016) contained mean and median concentrations of 3.2 and $3.15 \mathrm{mg} / \mathrm{kg}$ BP-F, respectively. The annual mustard consumption in the USA and Europe of approximately $16 \mathrm{oz}$. (454 g) per capita allows us to estimate the daily intake of BP-F via mustard, i.e., approximately 1-2 g/person/day (Table 1). In extreme situations, consumption may amount to $80 \mathrm{~g}$ mild mustard/person/day, which then calculates to approximately $11 \mu \mathrm{g}$ BP-F/kg b.w./day. As BP-F has been demonstrated to have endocrine disruptive characteristics (Rochester and Bolden 2015), should we therefore ban

Daniel R. Dietrich

Daniel.Dietrich@uni-konstanz.de

Jan G. Hengstler

hengstler@ifado.de

1 Human and Environmental Toxicology, Faculty of Biology, University of Konstanz, Universitätsstrasse 10, 78457 Konstanz, Germany

2 Leibniz Research Centre for Working Environment and Human Factors, TU Dortmund, Ardeystr. 67, 44139 Dortmund, Germany sweet/mild mustard? The answer of Zoller and colleagues is no. Based on a LOAEL of $20 \mathrm{mg} / \mathrm{kg} /$ day from a 28 -day repeated-dose toxicity study in rats (Higashihara et al. 2007) and an uncertainty factor of 1800 (100 for inter-species and inter-individual differences, 3 for using LOEAL instead of NOAEL, 6 for using a subacute instead of a chronic study), the authors calculated a tolerable daily intake value (TDI) of $11 \mu \mathrm{g} \mathrm{BP-F/kg} \mathrm{body} \mathrm{weight/day} \mathrm{(Zoller} \mathrm{et} \mathrm{al.} \mathrm{2016).}$ This value is in the same order of magnitude as $4 \mu \mathrm{g} / \mathrm{kg} /$ day, the current t-TDI of BP-A, which has recently been recommended to serve as a provisional TDI also for BP-F (BfR 2015). Both values, 4 and $11 \mu \mathrm{g} / \mathrm{kg} / \mathrm{day}$, can be considered as conservative, but supportable in view of the lack of available data for BP-F. Thus, although theoretically not impossible, only a very few hard-nosed mustard eaters will occasionally be able to surpass these daily intake values. It is therefore understandable and, based on the existing evidence, absolutely logic that a ban of mustard is not seriously considered (see also BfR 2015).

However, it is interesting to compare this situation to the discussion about BP-A, which peaked with national bans of some consumer products (Hengstler et al. 2011). Let us first compare toxicity data of BP-A and BP-F (Table 2). Both structurally related compounds have shown similar hormonal activities (Rochester and Bolden 2015). The LOAEL of BP-A was obtained from a three-generation study in Sprague-Dawley rats where $0.003,0.03,0.3,5,50$ and $600 \mathrm{mg} \mathrm{BP}-\mathrm{A} / \mathrm{kg} /$ day were tested (Tyl et al. 2008). In this study, $5 \mathrm{mg} / \mathrm{kg} /$ day was identified as NOAEL, while $50 \mathrm{mg} /$ $\mathrm{kg} /$ day decreased liver and kidney weights. At a later reassessment of the BP-A datasets, EFSA used this set of data to calculate a benchmark dose $\left(\mathrm{BMDL}_{10}\right)$ of $8.96 \mathrm{mg} / \mathrm{kg} /$ day for changes of the mean relative kidney weight (EFSA Panel 2015). In contrast to BP-A, no long-term studies are available for BP-F. In a repeated-dose toxicity study (28 days, 
Table 1 Daily uptake of bisphenol A and bisphenol F

\begin{tabular}{llll}
\hline & Daily consumption of mustard $(\mathrm{g})$ & Content of BP-F $(\mu \mathrm{g})$ & Daily BP-F intake of a 60 kg person $(\mu \mathrm{g} / \mathrm{kg} / \mathrm{day})$ \\
\hline$B P-F$ & & & \\
Average consumer & $1-2$ & $8.4-16.7$ & $0.14-0.28$ \\
High but relatively frequent & 20 & 167 & 2.8 \\
Extreme but not impossible & 80 & 668 & 11.1 \\
\hline
\end{tabular}

Recently estimated BP-A dietary intake by EFSA (EFSA Journal 2015)

$B P-A$

Infants and toddlers

Women of childbearing age and men of the similar age

Up to $0.875 \mu \mathrm{g} / \mathrm{kg}$ bw per day

Highest aggregated exposure for adolescents

Up to $0.388 \mu \mathrm{g} / \mathrm{kg}$ bw per day

$1.449 \mu \mathrm{g} / \mathrm{kg}$ bw per day

Bisphenol F (BP-F) uptake is calculated based on consumption of mustard only

Calculations are based on the highest value of $8.35 \mathrm{mg} / \mathrm{kg}$ measured in commercial samples of mustard (Zoller et al. 2016). Therefore, a daily uptake of $11 \mu \mathrm{g} / \mathrm{kg} /$ day represents an extreme scenario for very high consumption of mustard with the highest measured BP-F content. Very high BP-F concentrations are found only in 'mild' mustard (Zoller et al. 2016). Daily uptake values of bisphenol A (BP-A) were obtained from a recent EFSA study (EFSA Journal 2015)

Table 2 Toxicity of bisphenol $\mathrm{F}$ and bisphenol A (BP-F and BP-A) in rats and derived preliminary tolerable daily intake values

\begin{tabular}{lll}
\hline & BP-F & BP-A \\
\hline NOAEL & Unknown & $5 \mathrm{mg} / \mathrm{kg} /$ day $^{\mathrm{b}}$ \\
LOAEL & $20 \mathrm{mg} / \mathrm{kg} /$ day $^{\mathrm{a}}$ & $50 \mathrm{mg} / \mathrm{kg} / \mathrm{day}^{\mathrm{b}}$ \\
BMDL $_{10}$ & Unknown & $8.96 \mathrm{mg} / \mathrm{kg} / \mathrm{day}^{\mathrm{c}}$ \\
Tolerable daily intake & $11 \mu \mathrm{g} / \mathrm{kg} /$ day $^{\mathrm{a}}$ & $4 \mu \mathrm{g} / \mathrm{kg} / \mathrm{day}^{\mathrm{c}}$ \\
& & \\
\hline
\end{tabular}

${ }^{\text {a }}$ From Zoller et al. (2016)

${ }^{\mathrm{b}}$ From Tyl et al. (2008)

c From EFSA CEF Panel (2015)

rats), doses of 20, 100 and $500 \mathrm{mg} \mathrm{BP}-\mathrm{F} / \mathrm{kg} /$ day were tested by gavage (Higashihara et al. 2007). Already at the lowest tested dose of $20 \mathrm{mg} / \mathrm{kg} /$ day, BP-F was reported to decrease body weight as well as cholesterol, glucose and albumin levels, while serum thyroxin levels of female rats were increased, also an indication of a potential hormonal effect. Therefore, there is so far no evidence that BP-F can be considered as being less toxic or endocrinologically active than BP-A. Let us next move on to human exposure. Daily uptake of BP-F may range between 0.14 and $2.8 \mu \mathrm{g} / \mathrm{kg}$, depending on the individual mustard consumption, while the highest reported aggregated exposure values for BP-A has been reported to be $1.449 \mu \mathrm{g} / \mathrm{kg} /$ day (Table 1; Zoller et al. 2016; EFSA 2015). The highest values obtained in a recent study with human urine samples were $212 \mathrm{ng} / \mathrm{ml}$ for BP-F and $37.7 \mathrm{ng} / \mathrm{ml}$ for BP-A (Zhou et al. 2014; discussed in Zoller et al. 2016). The mean values for BP-F and BP-A were 0.08 and $0.72 \mathrm{ng} / \mathrm{ml}$, respectively. This reflects a situation where exposure to BP-A appears to be more widespread, due to the different sources of exposure, while exposure to BP-F is associated with a given condiment, and thus, exposure can be much higher in a minority of the population, perhaps due to specific food preferences, such as high mustard consumption. The discussed numbers reveal the peculiarities of national bans of BP-A in some plastic consumer products. Suddenly, we realize that we have been exposed to the related BP-F in the same order of magnitude as BP-A by a popular delicacy for centuries. Indeed, sweet mustard has been documented earlier than the fourteenth century, where Pope John Paul XXII created a specific position in the Vatican called 'grand moutardier du pape' (mustard maker to the pope) in order to support his love for mustard-containing foods. Sweet mustard has been the start of the ball-park hot dog at the 1904 St. Louis World Exposition as well as being the basis of the Bavarian delicacy of Weisswürste, also since the fourteenth century. Moreover, Zoller et al. (2016) also reported BP-F being present in preserved bamboo shoots, as was reported already earlier from a survey of Chinese food (Liao and Kannan 2014). Thus, one could ask the question whether or not centuries of chronic low-dose or intermittent high-dose exposure to BP-F may have had a detrimental (endocrine) health effect in humans such as decreased fertility (Hauser et al. 2015) or increased obesity and diabetes type II (Legler et al. 2015). However, this seems unlikely, as disease epidemics such as obesity and the associated diabetes type II have profoundly appeared only in the last two decades in North America and Western Europe.

We hope that this insight will not lead to further hotheaded and medially driven governmental bans but to an era of science-based, systematic and well-balanced risk management that includes the evaluation of all compounds to which we are exposed, and not unrealistically strict legislation for only a small subset of chemicals, while ignoring similar natural sources of exposure. 


\section{References}

BfR (2015) http://www.bfr.bund.de/cm/343/bisphenol-f-in-senf-dasauftreten-von-unerwuenschten-wirkungen-auf-die-gesundheitdurch-gemessene-bpf-gehalte-ist-unwahrscheinlich.pdf

EFSA, CEF Panel (EFSA Panel on Food Contact Materials, Enzymes, Flavourings and Processing Aids) (2015) Scientific Opinion on the risks to public health related to the presence of bisphenol A (BPA) in foodstuffs: executive summary. EFSA Journal 2015 13(1):3978. doi:10.2903/j.efsa.2015.3978

Hauser R, Skakkebaek NE, Hass U, Toppari J, Juul A, Andersson AM, Kortenkamp A, Heindel JJ, Trasande L (2015) Male reproductive disorders, diseases, and costs of exposure to endocrine-disrupting chemicals in the European Union. J Clin Endocrinol Metab 100(4):1267-1277

Hengstler JG, Foth H, Gebel T, Kramer PJ, Lilienblum W, Schweinfurth H, Völkel W, Wollin KM, Gundert-Remy U (2011) Critical evaluation of key evidence on the human health hazards of exposure to bisphenol A. Crit Rev Toxicol 41(4):263-291. doi:10.310 9/10408444.2011.558487

Higashihara N, Shiraishi K, Miyata K, Oshima Y, Minobe Y, Yamasaki K (2007) Subacute oral toxicity study of bisphenol F based on the draft protocol for the "Enhanced OECD Test Guideline no. 407". Arch Toxicol 81(12):825-832

Legler J, Fletcher T, Govarts E, Porta M, Blumberg B, Heindel JJ, Trasande L (2015) Obesity, diabetes, and associated costs of exposure to endocrine-disrupting chemicals in the European Union. J Clin Endocrinol Metab 100(4):1278-1288

Liao L, Kannan C (2014) A survey of bisphenol A and other bisphenol analogues in foodstuffs from nine cities in China. Food Addit Contam Part A 31(2):319-329

Rochester JR, Bolden AL (2015) Bisphenol S and F: a systematic review and comparison of the hormonal activity of bisphenol a substitutes. Environ Health Perspect 7:643-650. doi:10.1289/ ehp.1408989

Tyl RW, Myers CB, Marr MC, Sloan CS, Castillo NP, Veselica MM, Seely JC, Dimond SS, Van Miller JP, Shiotsuka RN, Beyer D, Hentges SG, Waechter JM Jr (2008) Two-generation reproductive toxicity study of dietary bisphenol A in CD-1 (Swiss) mice. Toxicol Sci 104(2):362-384. doi:10.1093/toxsci/kfn084

Zhou X, Kramer JP, Calafat AM, Ye X (2014) Automated on-line column-switching high performance liquid chromatography isotope dilution tandem mass spectrometry method for the quantification of bisphenol A, bisphenol F, bisphenol S, and 11 other phenols in urine. J Chromatogr B Analyt Technol Biomed Life Sci 1(944):152-156. doi:10.1016/j.jchromb.2013.11.009

Zoller O, Brüschweiler BJ, Magnin R, Reinhard H, Rhyn P, Rupp H, Zeltner S, Felleisen R (2016) Natural occurrence of bisphenol F in mustard. Food Addit Contam Part A Chem Anal Control Expo Risk Assess 33(1):137-146. doi:10.1080/19440049.2015.1110623 